\title{
Paideusis
}

\section{In Memory: Ronald F. Reed 1946-1998}

\section{John Portelli}

Volume 12, Number 1, 1998

URI: https://id.erudit.org/iderudit/1073092ar

DOI: https://doi.org/10.7202/1073092ar

See table of contents

Publisher(s)

Canadian Philosophy of Education Society

ISSN

0838-4517 (print)

1916-0348 (digital)

Explore this journal

Cite this article

Portelli, J. (1998). In Memory: Ronald F. Reed 1946-1998. Paideusis, 12(1), 5-6.

https://doi.org/10.7202/1073092ar

This document is protected by copyright law. Use of the services of Erudit (including reproduction) is subject to its terms and conditions, which can be viewed online.

https://apropos.erudit.org/en/users/policy-on-use/
This article is disseminated and preserved by Érudit.

Érudit is a non-profit inter-university consortium of the Université de Montréal, Université Laval, and the Université du Québec à Montréal. Its mission is to promote and disseminate research.

https://www.erudit.org/en/ 


\section{In Memory}

\section{Ronald F. Reed \\ 1946-1998}

Ronald Reed died on August 23, 1998 at the age of 52. He was a distinguished faculty member at the Texas Wesleyan University, a fine human being, and one of the early and hard-working contributors to the development of philosophy for children.

Originally from New York, Dr. Reed earned his B.A. from St. Francis College, Brooklyn (1968), his M.A. from City University of New York (1971), and his Ph.D. from the University of Western Ontario (1976). In 1979, he joined the faculty at Texas Wesleyan College in Fort Worth as the director of the Analytic Thinking for Children Program. Under his direction, the program become a major centre for the preparation of teachers interested in developing philosophical discussions in schools.

Dr. Reed's contribution to philosophy for children was varied and unceasing. He worked with hundreds of teachers who passed through the program he developed. In 1980, he founded the journal Analytic Teaching which he edited until 1991. He edited the Bulletin of the International Council for Philosophical Inquiry with Children (1988-91); he was president of the International Council for Philosophical Inquiry with Children (1989-90); and from 1993, he was director of the Center for Creative and Critical Teaching at Texas Wesleyan University. Dr. Reed directed several workshops and participated in several international conferences on philosophy for children in the USA, Canada, Spain, Germany, Denmark, Ireland, Mexico, Brazil, and Australia. One of his most recent contributions was to the UNESCO conference on philosophy for children in Paris. His last presentation at a Canadian conference was to the Canadian Philosophy of Education Society at Brock University in 1996.

Dr. Reed was a prolific author in the areas of philosophy of education and philosophy for children. He presented and/or published over 130 papers, and authored, co-authored, or edited over eight books. His papers appear in journals such as Teaching Philosophy, Thinking, Analytic Teaching, Research in Education, Insights, Vitae Scholasticae, Journal of Educational Studies, Journal of Teacher Education, Young Children, Ethics, Filosophia, Australian Thinking, Critical and Creative Thinking, and Australasian Journal of Philosophy. His books include Talking with Children (1983), Studies in Philosophy for Children (1992, with Ann Margaret Sharp), When We Talk: Essays on Classroom Conversation (1992), Philosophical Documents in Education (1995, with Tony Johnson), Children, Philosophy, and Democracy (1995, with John P. Portelli), Studies in Philosophy for Children, Vol. 2 (1996, with Ann Margaret Sharp), and Intellectual Friendship and Moral Education (1988, with Tony Johnson). He also wrote children's stories intended for use in philosophical discussions with children. The most popular of these is Rebecca which has been translated into German, Danish, and Portuguese. Dr. Reed's literary scholarship is exhibited in his reviews of both fiction and non-fiction books. He published over 400 book reviews in the Fort Worth Star-Telegram, Dallas Morning News, and Texas Review of Books. 
In 1996, Dr. Reed became the Bebensee University Scholar at Texas Wesleyan University. During his teaching career, he taught at other universities as a visiting scholar includimg University of Texas at San Antonio, Viterbo College, and Montclair State College.

Ronald F. Reed was a fine scholar, a great teacher, and a generous human being. Jake B. Schrum, President of Texas Wesleyan University noted: "Ron Reed was a great respecter of opinions. He always had an open mind and an open heart, and measured success not by students' answers but by their questions. He constantly urged his colleagues to think across the disciplines in order to enrich their world view." His contributions to philosophy of education, philosophy for children, and teaching will be greatly missed.

Dr. Reed is survived by his wife, Ann Reed; son, Jeremy Reed; and daughter and son-in-law, Rebecca and Wade Pfleger.

John Portelli 